\title{
The Company Efficiency Increasing Strategy in Makassar Contract Terminal Using Quantitative Strategic Planning Matrix
}

\author{
Siti Haerani', Muhammad Yunus Amar², Muhammad Iskandar ${ }^{3}$ and A. Sugeng S. Aji ${ }^{4}$ \\ ${ }^{1}$ Hasanuddin University, Indonesia, e-mail: haeranisiti68@yahoo.co.id \\ ${ }^{2}$ Hasanuddin University, Indonesia \\ ${ }^{3}$ Hasanuddin University, Indonesia \\ ${ }^{4}$ Indonesia Economics College Makassar, Indonesia
}

\begin{abstract}
The company's operational strategy related to the supply of goods and services will be much better if through coordination and communication so that the operational activities of the company run efficiently and effectively. This study aims to identify internal and external environmental factors that affect the level of fuel consumption and determine business strategy at Makassar Container Terminal. This study is a type of qualitative research on the strategy that identifies and develops operational efficiency strategies. The decision of managerial strategy in this research covers the result of QSPM which is determined based on the analysis of the internal and external environment of the company. The result of the research shows that the internal environment factors that influence the efficiency of energy consumption in Makassar Container Terminal are efficiency service orientation and effectiveness, modern facilities and equipment, international standard services, professional SMDs, and dock facilities support. A business strategy that can be used to improve the fuel efficiency of Makassar Petikemas Terminal is to convert fuel oil to Gas Fuel. It can be supported with supporting infrastructure such as converter kits for each company vehicle Keywords: QSPM, Efficiency Strategy, Business Strategy
\end{abstract}

\section{Introduction}

Strategic planning is the backbone of strategic management, where strategic planning is more related to operational activities and more inclined to discuss strategic issues rather than operational problems (Burhan: 1994). There is also a saying that strategic planning is a systematic effort that is oriented towards the future and involves all managers and members of other organizations. An effective and well-implemented strategic plan will realize that the organization will have a general ability to manage external change (Owolabi \& Makinde, 2012).

Changes in the company's internal and external environments can have an impact on the company's operational efficiency, so it will be a priority consideration for companies in dealing with business competition (Aranda, 2003). Employees who are experts in various tasks and jobs can generate ideas that are about making the process change more efficient (Jones \& Linderman, 2013).

Measuring the level of efficiency at the company is an important discussion for managers and investors. Customers will benefit from the efficient and effective use of resources at lower rates/ prices and better services (Mostafa, 2007). Cerin \& Laestadius (2003) further explained that the company's efficiency program in the form of credit enhancement and sustainable operational activities, the management system is required to pay attention to efficiency aspect especially on company units to become a profit.

Container terminal as one of the port business support facilities that have core business on loading and unloading. Transportation activities through containers facilitate the incorporation of goods into containers so that loading and unloading activities at ports can be more effective. Freight system using a container into a service business more effective than other freight systems. Container transport has some virtues that are guaranteed goods security, the speed of loading and unloading process and vice versa. But in the process of implementation, it is a necessary strategy for the more efficient use of resources used. 
Efficiency in this research more specifically focused on the energy aspect in the form of fuel oil usage. Currently, the port industry in container operational activities still uses a large amount of energy. This condition is inseparable from the use of the company's equipment which is still dominant using fuel oil, so this issue becomes a very important topic to reduce the use of fuel oil by adopting certain technology, in the seaport industry known as "The Green Port Concept" (Pavlic et al., 2014).

PT Pelabuhan Indonesia IV (Persero) as a state-owned corporation that manages container services has several container terminals such as Makassar Petikemas (TPM) Terminal. The development of an internal and external environment of the Makassar Container Terminal which requires management to be wiser in taking strategic decisions, and improving the quality of container services, the effectiveness and efficiency must be increased in order to improve the performance of the company. Makassar Container Terminal requires an operational strategy to manage container service activities in line with the increasing flow of vessels and the flow of goods both internationally and domestically through Makassar Port along with the growth of container flow in 2015 which has increased compared to 2014, though in 2013 the current level of containers both domestically and abroad are experiencing the highest increase.

\section{Research Methodology}

This research is a library research.

\section{Result and Discussion}

External and Internal Environmental Conditions. An analysis of all the internal conditions that have been collected to obtain the appropriate and relevant conditions as Strength and Weakness, where the conditions are the input for the formation of a new strategy. The internal condition of the company's environment is analyzed based on the results of questionnaires and interviews to informants to see a comparative comparison of the strengths and weaknesses of the company's internal conditions.

Based on the company's external data collection, a list of external conditions indicates a stable investment climate can be an opportunity for foreigners to look for investment opportunities in container terminals, especially on investment in operational activities (equipment and superstructure), government policy on fuel oil saving program, movement campaign of fuel oil conversion program to gas fuel, exclusive rights of Port to be utilized in conducting efficiency of fuel consumption at Makassar Petikemas Terminal, Trend The Green Port Concept becomes an opportunity for Makassar Petikemas Terminal to adopt environmentally friendly and efficient energy, limitations/scarcity of alternative fuels

The internal condition of the company, obtained the internal conditions of service-oriented to the efficiency of cost and time effectiveness, the availability of modern facilities and equipment, applying international standard container service system, professional human resources, dock facility with a length of 1,000 meters and 9 meters width with the depth of the pool -9 / -12 MLWS, inefficient use of loading and unloading utilities at ports and container depots, waste of fuel consumption, and high logistics and transportation costs

Analysis of IFAS and EFAS. In the next stage the analysis of all the internal conditions that have been collected to obtain the appropriate conditions and relevant as Strength and Weakness, where the condition becomes the input of the formation of a new strategy. Strategic factors are the dominant factors of strengths, weaknesses, opportunities, and threats that affect the existing conditions and situations and provide benefits when positive action is taken. (Robert G. Dyson, 2004).

The internal condition of the company's environment is analyzed based on the results of the questionnaires and interviews to the informants to see the comparative comparison of the strengths and weaknesses of the company's internal conditions which are further compiled so as to know the advantages and disadvantages of this company. For the advantages of service orientation efficiency and effectiveness, modern facilities and equipment, international standard services, professional 
human resources, as well as support dock facilities. The weaknesses are the inefficiency of utility use, the waste of energy consumption, and the cost of logistics and transportation

SWOT analysis. SWOT Matrix describes various alternative strategies that can be done based on SWOT analysis (Purnomo, Zulkieflimansyah, 1999). The most important activity in the SWOT analysis process is to understand all the information in a case, analyze the situation to find out what issues are going on and decide what action should be taken to solve the problem (Freddy Rangkuti, 2001: 14). According to Jogiyanto (2005), SWOT is used to assess the strengths and weaknesses of the company's resources and external opportunities and the challenges it faces.

The SWOT analysis has four strategic nature quadrants consisting of (i) aggressive, (ii) conservative, (iii) defensive, and (iv) competitive. The first strategy: An aggressive position is a perfect position to use internal strengths in exploiting the advantages of external opportunities, overcoming internal weaknesses, facing external threats. The strategies are market penetration, development, and backward integration, forward integration, horizontal integration, conglomerate diversification, concentric diversification, horizontal diversification. The second strategy: In the conservative position, showing the basic competence and not taking risks. The strategy is penetration, development, and concentric diversification. Third strategy: Companies in defensive positions should focus on fixing internal weaknesses and facing external threats. Selected strategies are retrenchment, divestiture, liquidation, concentric diversification. The fourth strategy: competitive position, showing competitive strategy consisting of penetration, backward integration, forward integration, horizontal integration, and joint ventures.

The details of the strategy can be summarized as follows:

a) Concentrated Growth (market penetration). A strategy that directs its resources to the profitable growth of only one product, in one market, with one dominant technology.

b) Market development is a modification of current product marketing to customers within the scope of the associated market, by adding distribution channels or changing marketing communications. This strategy is also called market expansion by entering new markets.

c) Product development includes substantial modification of existing products or the creation of new and related products that can be marketed to customers through existing distribution channels. Product development strategies are used both to extend product life and to benefit from reputations or brands.

d) The Innovative strategy is the result of innovative thoughts and ideas on the product so that it has more, or superior performance compared with other similar products. Unlike product development that modifies products to extend the product lifecycle, this strategy is to create new products or new product life cycles.

e) Horizontal Integration. This strategy is done by gaining ownership or increasing control over competitors in the same business as the company. This strategy usually acquires or expropriates against similar companies.

f) Vertical integration strategy consists of backward vertical integration and forwards vertical integration. Backward integration is gaining ownership or increasing control over suppliers or raw material networks, while forward integration is gaining ownership or increasing control over distribution channels. In other words, the forward integration acquired the distribution network company while the backward integration acquired the supplier company.

g) Joint Ventures (joint ventures). Two or more companies work together to form a new company separate from their respective parent. Each unites its resources in a new company.

h) The concentric diversification strategy is to add new, interconnected products to the same market or enter a new business closely linked to today's main business.

i) The conglomerate diversification strategy is to add new, unrelated products to different markets or enter new businesses that are totally unrelated to today's main business. 
j) Retrenchment and Turnaround. This strategy is cost savings by reducing some of the company's assets or overhead costs such as labor and equipment costs, with the aim of tackling the decline in sales and profits.

k) Divestiture (business downsizing). Strategy by selling a business unit or part of a company with the aim of improving the company's performance. This strategy is used usually after the used retrenchment strategy fails. This strategy is often referred to as business shrinkage

1) Liquidation strategy is the company's final way of failure in the company's performance by selling all the assets of the company or in other words closing the company.

QSPM analysis. The next stage in the formulation of an effective business strategy for the development of Makassar Container Terminal is the decision stage or the selection of business strategy using quantitative strategic planning matrix (QSPM).

The QSPM matrix is the matrix used in the decision stage to see the relative levels of the various alternatives that can be implemented resulting from the matching stage. QSPM uses input from the first stage (input stage) and the second stage (the matching stage) that provides information for the third stage (the decision stage) (David, 2004)

The QSPM matrix is needed to evaluate the alternative choice of strategies objectively and is designed to determine the relative attractiveness and feasible action alternatives based on the analysis results in the TOWS analysis phase, the QSPM matrix is also used as a strategy recommendation to be implemented by the company in the future.

Based on the calculation of QSPM, the alternatives to the conversion strategy of Fuel Oil to Gas Fuel by providing supporting infrastructure such as converter kit for each vehicle company has a higher score of 4.12 compared to other strategic alternatives. TAS (Total Attractiveness Score) assessment is done objectively by looking at the linkage of existing factors on the left side of the table with available alternative strategies.

\section{Conclusion}

Internal environmental factors that affect the efficiency of energy consumption in Makassar Container Terminal include service orientation efficiency and effectiveness, modern facilities and equipment, international standard services, professional SMD, and dock facilities support. While the external environmental factors that affect the efficiency of energy consumption in Makassar Petikemas Terminal is a stable investment climate, fuel oil savings program, the conversion of fuel oil to gas fuel, exclusive port rights, and the concept of The Green Port.

The Business strategy that can be used to improve fuel efficiency at Makassar Container Terminal is the conversion of BBM to Fuel Gas by providing supporting infrastructure such as converter kit for each company vehicle.

From the results of this study, the priority scale of the predefined strategy is expected to be implemented within the organization, so that fuel costs can be reduced to increase the productivity of loading and unloading activities and still prioritize excellent service to the port customers.

\section{References}

Aranda, D.A. (2003). Service operations strategy, flexibility, and performance in engineering consulting firms. International Journal of Operations \& Production Management, Vol. 23, No. 11.

Burhan, N. (1994). Strategic Planning. Jakarta: LPPM dan Pustaka Binaman

Cerin, P., \& Laestadius, S. (2003). The efficiency of becoming eco-efficient. Management of Environmental Quality: An International Journal. Vol. 14, Iss 2.

David, F.R. 2004. "Strategic Management: Concepts. Seventh edition ". PT. Prenhallindo, Jakarta

Dyson, Robert. G. 2004. Strategic Development and SWOT analysis at the University of Warwick. Journal. European Journal of Operation Research. Warwick.

Jogiyanto 2005. Analysis and Design of Information Systems. Andi. Yogyakarta 
Jones, Janine L. S. \& Linderman, K. (2013). Process management, innovation, and efficiency performance. The moderating effect of competitive intensity. Business Process Management Journal. Vol. 20, No. 2.

Mostafa, M. (2007). Benchmarking top Arab banks' efficiency through efficient frontier analysis. Industrial Management \& Data Systems.Vol. 107, Iss. 6.

Owolabi, S.A., \& Makinde, O.G., (2012). The Effects of Strategic Planning on Corporate Performance in University Education: A study of Babcock University. Kuwait Chapter of Arabian Journal of Business and Management Review, Vol. 2, No. 4.

Pavlic, B., Franka Cepak., Boris Sucic., Marko Peckaj., and Bogomil Kandus. (2014). Sustainable Port Infrastructure, Practical Implementation of The Green Port Concept. Thermal Science, Vol. 18, No. 3, pp. 935-948

Purnomo, Setiawan \& Zulkieflimansyah. 1999. Strategic Management. FE-UI. Jakarta.

Rangkuti, F. (2001). SWOT Analysis Techniques Dissecting Business Cases. Jakarta: PT Gramedia Pustaka Utama. 62 